\title{
SLOW RESEARCH: EXPLORING ONE'S OWN VISUAL ARCHIVE
}

Marcus Banks

University of Oxford

\begin{abstract}
This article considers the "pace" of research, particularly with regard to the role played by film and photographs in setting or subverting this pace. Drawing on examples from published sources and my own visual archive, photographs taken during the course of fieldwork in India and England in the 1980s and 1990s, I consider ways in which photographs and other images can be revised and explored for new insights.
\end{abstract}

Keywords: India, photography, slow cities, Jamnagar, New Guinea, Seven-Up

\section{INTRODUCTION}

Since I became involved in the field of visual methods, around 15 years ago, I have been struck by just how much visual research in the social sciences is underway or in the planning. ${ }^{1}$ One of my regrets however is how rarely I have been able to follow up some of the research I have heard about at conferences and workshops, to see how things turned out. In part this is due to the relatively transitory nature of some of the research. In the UK academic environment there is increasing pressure to keep moving on, to apply for new research grants and begin new projects even before the final report has been written on the previous project. Social science academics today are not encouraged to mull things over, or to revisit old ideas or old data, and in this sense "pure" academic research is increasingly being replaced by an agenda that resembles commissioned contract research.

My stimulation for thinking about "slow" research has arisen from Sarah Pink's work on the "slow city" (cittaslow) movement (Pink 2008). The slow city movement is an outgrowth and development of the "slow food" movement, with an emphasis on enhancing local values of

\footnotetext{
1 Many of the anglophone results of this research can be found in journals such as Visual Communication,
} Visual Anthropology, Visual Studies, and so forth. 
community in urban spaces. My interest in "slowness" in this paper is rather more literal than Pink's, though I share with her an interest in the "pace" of research and the "pace" of the lives lived by our research subjects.

\section{WALKING}

In a variety of presentations and publications over the past few years Pink has described research she has conducted in the British slow cities of Alysham and Diss, both in Norfolk in the east of the country (see 2008), using a research method she describes as "walking with video" (2007). For example, she describes three walks she took in Aylesham in a community garden, a patch of bare land that between 2005 and 2007 was transformed into a garden of flowers and trees for local community use. She undertook the walks with the Chairman of the transformation project and used her video camera to document but also to mirror and mimic the speech and actions of the Chairman as he called her attention to aspects of the developing garden. For example, as the Chairman pointed out to her some sunflowers that had been blown over by recent heavy gales his actions served to "[draw] the camera toward them" (2009: 109). Furthermore, as he took Pink on the most recent tour of the garden he made reference to his - and her - memories over the past two years, reminding her of how the "firm dry path" now provided a safe and easy way to negotiate what had once been a "muddy and bare" plot. As Pink says: "Being there, in the garden, with a video camera, offers a way of accessing [the] sensorial aspects of the process of the development and experiences of it as well as some understanding of the memories and imaginaries associated with it" (Pink 2009: 110). In this piece of work, and in others, Pink has combined the insights of the ethnographic filmmaker David MacDougall (who argues for a phenomenological use of the camera to access the embodied experiences of research subjects - 2006: 24) with the insights of the anthropologist Tim Ingold (who argues for closer methodological attention to be paid to walking as a fundamental part of human experience - Ingold and Vergunst 2008).

Yet although the speed of locomotion dictated by walking has influenced the pace of human action in the world for millennia, walking pace may not always be the most appropriate research pace by which to study society in the industrial and post-industrial world. In recent years scholars have sought to capture the profound social and sensory changes that came about with industrialization and automotive locomotion in the nineteenth century. For example, at the very start of her account of Eadweard Muybridge's experiments with high speed, rapid sequence still photography in the 1870s, Rebecca Solnit sets the scene half a century earlier as she tries to convey just how perceptions of time and space were changing through rail travel: "Thirty-five miles an hour was nearly as fast as the fastest horse, and unlike a gallop, it could be sustained almost indefinitely. It was a dizzying speed. Passengers found the landscape out the train windows was blurred, impossible to contemplate, erased by speeds that would now seem a slow crawl to us" (Solnit 2003: 9).

I will return to exploring the relationship between change, time and photography at the end of this paper with reference to some of my own work. What is relevant now is to try and establish the value of a relationship between the pace of the research and the pace of the lives of those we study, seeking to distance this as far as possible - at least in terms of analysis - from the pace of academic life and the funding cycles of research agencies. Such distancing can only 
ever be an heuristic exercise in the vast majority of cases as few if any of us have the luxury of fully-funded, time-unlimited research. Sarah Pink herself refers to her reflections on walking with video in the Aylsham community garden as being derived from the "(to date) final video tour undertaken in 2007" (2009: 107), giving the distinct sense that while the garden and those that care for it will continue to grow and develop she may no longer be able to participate in the process.

\section{LONGITUDINAL RESEARCH?}

It is worth asking at this point whether taking account of the role of time in the research process and in the lives of the people we study is equivalent to longitudinal research. And additionally, is there a role for visual methodologies in such research?

Within the discipline of social anthropology formal longitudinal research (see Ruspini 2000 for an overview) is not common. Of course, there are many anthropologists who continue to visit their study population for many years after their initial period of fieldwork, but such visits are often made with the aim of conducting new projects rather than following up old ones. ${ }^{2}$ And in general anthropologists do not collect the kinds of quantifiable data that are amenable to re-collection for time-lapsed comparative purposes.

Moreover, few longitudinal qualitative studies actually seem to have started out as such, rather they have developed and taken on a life of their own through a combination of circumstances. What is clear, however, is that over the twentieth century anthropological approaches to time and social change have been massively revised. George Foster et al, for example, point to the case of the American anthropologist Robert Lowie who, despite conducting research on Crow native American people between 1907 and 1931 felt able to say in his 1959 autobiography "The Crow experiences form a continuum in my consciousness. Therefore I shall not give a separate account of each visit, but shall treat them all as a constituting a single phenomenon" (1959: 42, cited in Foster et al 1979: 4).

However, while qualitative anthropological researchers do not necessarily have formal longitudinal research agendas, and thus no data from previous research visits to the field that can be formally compared with later data, they do accumulate large amounts of qualitative insights and - more particularly - maintain continuity of social relationships over many years. In this there are some parallels with the cittaslow / slow city movement where the developing quality and depth of social relationships among a town's inhabitants are as important as the "localness" of the food or the employment.

In their comprehensive 1979 volume of essays on long-term field research Foster et al and their contributors make no references to film, and only a handful to the role of photography - one of which is to the use of aerial photographs taken over time in Chiapas, Mexico, to study changing settlement and land tenure patterns (see Vogt 1974). It remains to be explored therefore whether there can be an explicitly visual component to this informal, qualitative lon-

2 The conduct of ethnographic fieldwork often aims to be transformative of the research process and the research questions asked (see Parkin 2000). In this sense, few anthropologists would wish to be methodologically constrained by research agendas generated years or even decades before (see Goodman 2000). 
gitudinal approach. Three decades after Foster et al's volume, White (2009), in her exploration of the field still found very little, or at least none that has been formally assessed and published.

With regard to potential applications, White considers two existing film projects, one explicitly longitudinal but not anthropological, the other much more explicitly anthropological but only serendipitously longitudinal. The first is the Granada Television (UK) series Seven-up developed by the director Michael Apted (see Singer and Apted 1998). In this series of films, an initial sample of fourteen British children have been filmed every seven years since 1964 (the year in which they all turned seven years of age): the most recent film was shot and screened in 2012. Of the various insights White has derived from the films, ${ }^{3}$ the one that interests me here is how, following repeated visits to the children (now of course adults), what initially seemed to be predictable trajectories to their lives became more complex and increasingly less predictable over the years. White quotes Scudder and Colson, two other anthropological writers on longterm research on this experience: "the people who are the focus of [longitudinal] study become more the product of their own history and less the exemplars of universal cultural patterns" (quoted in Kemper and Royce 2002: xxi, cited in White 2009: 3).

The second example considered by White is more directly related to anthropological concerns in that the films were produced by filmmakers working closely with anthropologists. Bob Connolly and Robin Anderson's "Highlands trilogy" (1983-1992) consists of three films which examine aspects of life among the Waghi people of the New Guinea highlands. The first film, First Contact (1983), makes extensive use of "first contact" material, shot by Australian gold prospectors in 1930, interspersed with interviews with Waghi descendents in the early 1980s. The remaining two films focus on these descendents over the next decade as they negotiate their relationships with the contemporary Papuan state and with their neighbour, the son of one of the original prospectors by a local woman. Again, the insights White (and others) have drawn from these films, covering in their ethnography a period of over half a century, are many, but what concerns me here are the small events they document that can have emotional and sociological ramifications many years later. Primary among these is that at one point in the 1930 footage one of the prospectors is shown with his arm around a young Waghi woman in what appears to be an intimate, if perhaps over-familiar way. What could not have been known at the time of shooting, and only emerges in the next two films, is that this is the start of a relationship that will in due course result in the birth of Joe, the protagonist of the next two films. As White says: "Unlike the $U_{p}$ series, the story of these films is one not of individuals but of relationships intertwined and evolving" (2009: 6).

Of course, that relationships are intertwined and evolve is neither a new insight, nor one exclusive to visual representation. What is true, however, is that it is perhaps much easier to make such connections through visual representation. Joe, the son of the 1930s prospector bears no great facial or other physical resemblance to his father. In the final film of the series (Black Harvest, 1992), however, he has a conversation with his father's younger brother who still lives in the highlands. The similarity between the two men, not just in looks but in behaviour, is evident, as it is between the now very elderly uncle in the 1990s and his older brother in the 1930s. Other connections can be easily discerned across the half-century of visual record (for example, the entrepreneurial ambitions of the original prospectors and those of Joe the descendent).

3 The films have also been used by psychologists (see Lanning et al 2009). 


\section{BreAtHing}

I will return to time and the longitudinal study in the final section of this paper. But first I want to consider what it means to let an image breathe; that is, to let the full range of the power of a photograph (or series of photographs) inform our research. I do this with reference to some of my own experiences with publishing photographs taken during the course of research.

In my first book (Banks 1992), an ethnographic study of the social organization of an Indian religious group in India and in the UK, I persuaded the publisher to let me include 20 photographs. Even in 1992 this was an unusually high number of images for an anthropological monograph and the series editor took some convincing, especially when I made it clear I didn't want a section of "plates", on glossy paper, to be bound as a separate section of the book, away from the main text. Emerging digital technologies in the publishing industry however allowed the production of good quality images on the same paper and on the same pages as the written text.

I ended up with a book where the images are interwoven with the text; each chapter is headed with an image, usually after a few lines of introductory text, and then another image is used later on in the chapter. None of the images are captioned on the page, merely numbered, nor are they referenced or discussed in the text; there is however a list of captions and I wrote a very short discussion about the use of the photographs in the book's Preface. The captions give the date and location of each photograph and a short passage which amplifies or contextualizes rather than describes the image content. My aim, as stated in the Preface, was not so much for the photographs "to 'illustrate' the text as to provide a parallel text which complements the written one" (Banks 1992: ix) and I followed this with what I now consider to be a pretentioussounding statement about the avoidance of reductive captioning and the closure of anthropological meaning. There was a logic and intended coherence to the sequence of the images, particularly two photographs taken at the start and close of a religious ritual which bookend the main text, and all the images were selected with an eye for aesthetic appeal (in my eyes anyway) as much as informational content (see Harper 1987).

In a later book, this time a co-edited volume of essays on visual anthropology, my co-editor Howard Morphy and I backed away from the rather extreme position on image autonomy I had attempted in 1992 and we did provide captions under the images for the 14 photographs we used in our introduction to the volume (Morphy and Banks 1997). However, we again did not refer to the images in the written text or cross-reference them in any way, and with a couple of exceptions, none of the images bore any direct ethnographic, bibliographic, or biographical connection to the written text (one exception, for example, was a fairly randomly-selected sequence of images from Bateson and Mead's 1942 Balinese character that directly followed a discussion of the book). Instead we selected images, and placed them in the text, to chime with ideas discussed in certain passages. For example, following a passage about the changing technology of photomechanical reproduction which briefly alludes to the rendering visible of "previously hidden worlds of sub-atomic particles" (1997: 23) but which then moves on into a discussion of visual authority and the interrogative stance of some contemporary photography, we placed an electron microscope image of partially crystallized silicon which, at first glance, resembles flower petals floating in a stream (we selected the image precisely because it had been published by its creator, a Japanese materials scientist, with the title "Cherry blossoms in a clear stream"). The aesthetic consideration underlying image selection for the introduction was 
slightly different too from my earlier attempt; this time my co-editor and I selected arresting or images that demanded to be seen (as in the case of an advertising image we used).

In both these cases - the 1992 monograph and the 1997 volume of essays - my intention was to allow the images to breathe, to be only loosely tethered to the written text's content and argument, and capable of providing an alternative narrative. As such, my thinking went, the reader would be less inclined to merely glance at the images and instead be forced or at least encouraged to engage with them as semi-autonomous entities - breathing and speaking with their own voices. To liberate images from text in this way might be, to quote Mitchell (2005), to allow them to achieve what they want.

From a review of the reviews, the experiments were failures, or at least passed unnoticed. None of the reviews of either book made any reference to the images used, nor has anyone ever said anything to me in any discussion about the two books. In the case of my 1992 ethnography this is less surprising: there is no discussion of the Jain religious group's visual world and the book is read, by and large, by Indologists and textual scholars interested in the particular religious tradition I studied. In the case of the co-edited volume, which explicitly addressed a visual agenda within anthropology, the failure of reviewers to comment on the upcaptioned images in the introduction is more surprising, though I can suggest some explanation. The images used in the book's essays after the introduction are more conventionally presented (they have largely descriptive captions that relate to the text and are sometimes directly cited in the text; this is also the case with my own essay, which is again about the Jain religious tradition). It is perhaps only in the case of the very self-consciously visual and even "designed" works -, such as Robert Gardner's 1969 Gardens of war or more recently Banerjee and Miller's book on the sari (2008), both of which use typography, page layout, and coloured text and backgrounds as well as photographs, that disrupt the normal linear experience of academic reading and encourage the reader to think "through" the images.

All these suggestions concern the reception of the published works, and make presumptions about the reader. As the author, however, I can also comment on the production and the producer. In both cases above, it was I as the author who made possible the conditions by which the photographs could "perform" (Elizabeth Edwards's resonant term - 1999: 49). Returning to the respiration metaphor, I created a sort of breathing chamber within which the images could have a voice, but only in the gaseous atmosphere I had prescribed. In one case at least, however, an image breathed and then spoke in its own way.

In my 1992 ethnography of the Jain religious group I had studied I included a photographic portrait of an elderly British Jain man who had been particularly helpful to me in my research and of whom indeed I was particularly fond (see Figure 1). I had consequently spent a great deal of time with him and his family while conducting the UK half of my field research. The photo was taken as part of a sequence of images in the middle of a ritual event in the UK Jain temple, though he did turn, stand straight and pose for this particular photograph. The caption for the image (printed separately from the image itself, as described above) read: "Zaverchandbhai treated me as much as a son as a friend, gently steering my course of enquiry and smoothing my progress" (1992: xv). I also used the image as the cover image for the book itself. At the time of the book's publication Zaverchand - who was a very modest and rather formal man - thanked me in a friendly but rather stiff fashion for using his photo as the cover image but gently chided me for giving him, rather than the religious tradition, so much 
prominence. I never actually asked him what he thought the cover image should have been of, but I assume he would have suggested one of the many photographs I had taken of temples in India, or an image of one of the religion's founders. As with all my portrait photographs, I gave Zaverchand an unmounted enlargement of the black and white image.

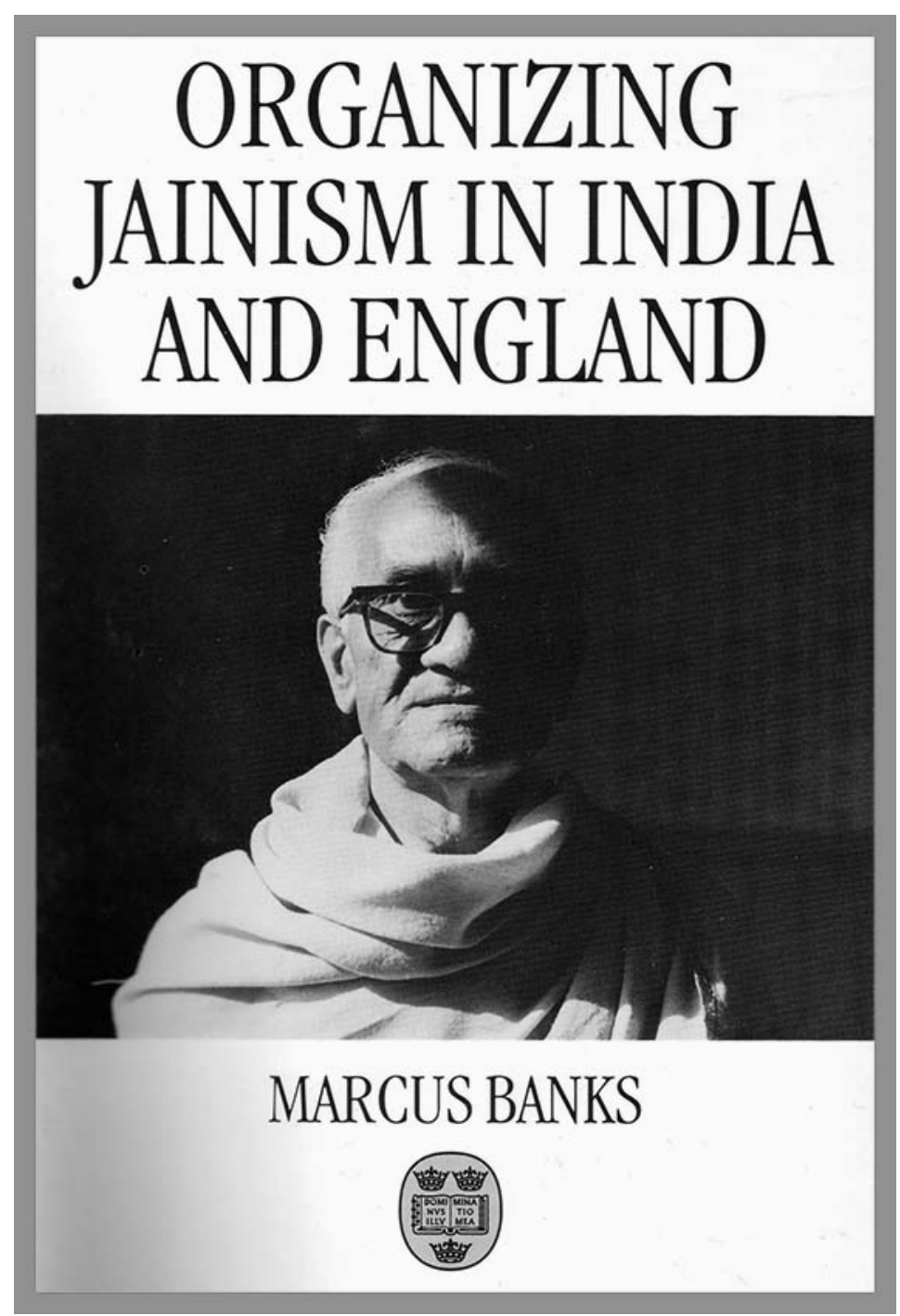

Figure 1

A decade or so later Zaverchand died peacefully, at a good age and after a successful, contented and very fulfilled life. At the pre-cremation funerary ceremonies in his younger son's home in the UK (where he had lived) I was rather taken aback to see the image I had taken, now framed, prominently displayed next to the coffin. His sons, and many of the other mourners, pointed it out to me as soon as I entered the room and at intervals over the next few hours. His younger son also made a special point of referring to us when introducing me to other mourners as "brothers" whose "father" had died. ${ }^{4}$ The image - and of course the relationship I had forged

4 Some linguistic unpacking is required here. With this family, who live in the UK, I largely speak in English, though we all use Gujarati terms on occasion. In Gujarati, adult men often refer to each other as "brother" - bhai - as a mark or respect or friendship; -bhai is also added as a suffix to names, hence "Zaverchandbhai". However, actual brothers do not add the suffix, especially when elder is addressing or referring to younger. During the funeral Zaverchand's younger son (but my senior by a few years), consistently addressed and referred to me as "brother" 
with the family over the years - seems to have made this transition from friend to kinsman possible. One further point is that I dedicated the 1992 book to my own father, who died after I had completed the research but before the book was published. Zaverchand had commented on this filial piety at the time, and his son reminded me of it at Zaverchand's funeral. This dedication, combined with the image's published caption and the image's subsequent life in the home of this family, seems to have provided the atmosphere the image needed to breathe. The photograph mediated a professional relationship (between myself as anthropologist and Zaverchand as informant) and a filial relationship, but the image seems to have "wanted" (in Mitchell's sense) the latter, and with Zaverchand's death brought this filial relationship to the fore.

\section{IMAGES OF CHANGE AND TRANSFORMATION}

I come now to my final example, again drawn from my own work in India. As I have described previously, my initial and continued research interest there in the 1980s and 1990s was on the organization of an Indian religious tradition, Jainism. However, as the Jains are a largely urban group in north India and as I had also studied Jain migrants in a British urban context, I almost inevitably developed a side interest in urban anthropology more generally. In particular, on my very first visit to the city of Jamnagar, in the western Indian state of Gujarat, I was struck by the distinctive architecture of the city and in a haphazard way set about photographing this distinctiveness.

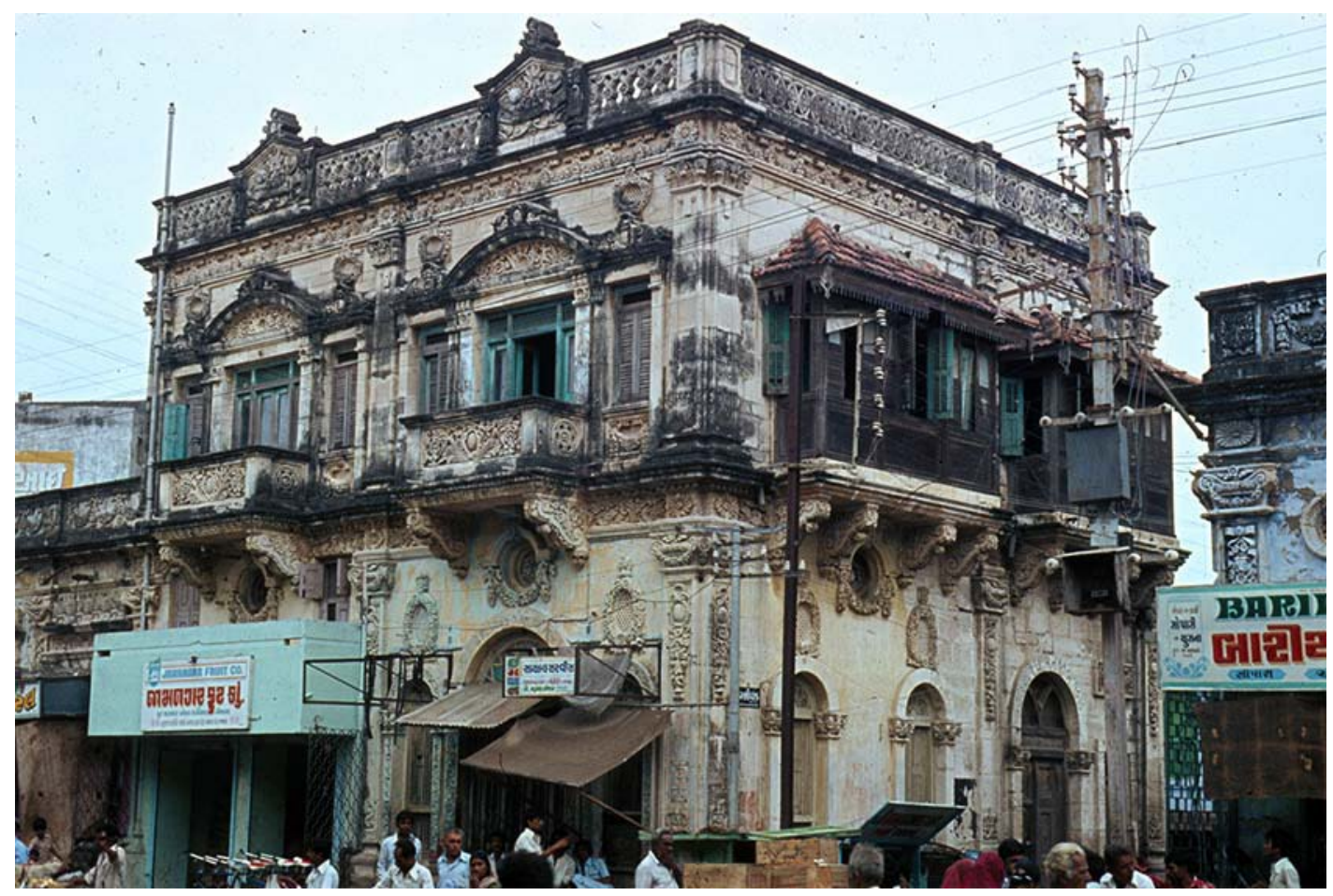

Figure 2

(in English) which had never happened before, instead of "bhai" or "Marcusbbai" as he had previously done. He also referred to his father as "bapuji" ([respected] father), encouraged me to do the same, and through speech patterns gently indicated it was no longer appropriate for me to refer directly to his father by his given name, with or without the "-bhai" suffix. 
I claim no great sociological insight from this ethnographic example, which is merely a methodological anecdote, but what it does prove, however, is that the images we take as social researchers can take on lives of their own when we give them space - and time - in which to breathe. They have the potential to do this of course whether we notice or not; what I am advocating here is a visual research methodology that remains attentive to this potentiality long after the funded period of research is concluded.

The city, although founded in 1540, was extensively remodelled in the early years of the twentieth century by its then ruler, ${ }^{5}$ Jam Ranjitsinji who had been impressed by the urban layout of European cities, to the extent that Jamnagar was sometimes known in Gazetteers and other documents as "The Paris of Saurashtra" (Saurashtra being the name of the region in Gujarat State). In part this label seems to derive from the wide, Haussmann-like sweep of the parades and boulevards that Ranjitsinji introduced, and in part from the rococo ornamentation applied to buildings and other, non-functional structures such as balustrades and pavilions (see Figure 2). In the centre of the city, for example, is a "tank" or reservoir which historically provided a fresh water supply during the long dry summer. Ranjitsinji's architectural transformations fringed the northern side of the reservoir with gardens, seats and decorative pavillions to create a recreational space for his subjects.

Figure 3 is a photograph I took shortly after arriving in Jamnagar for the first time in 1983; it shows the column of a decorative balustrade near to where I was staying that arbitrarily separated the road highway from a patch of scrubby grass ("arbitrary" in that the balustrade ran for a mere few metres and then simply stopped, leaving the road and scrubby grass to continue in proximity on either side of it).

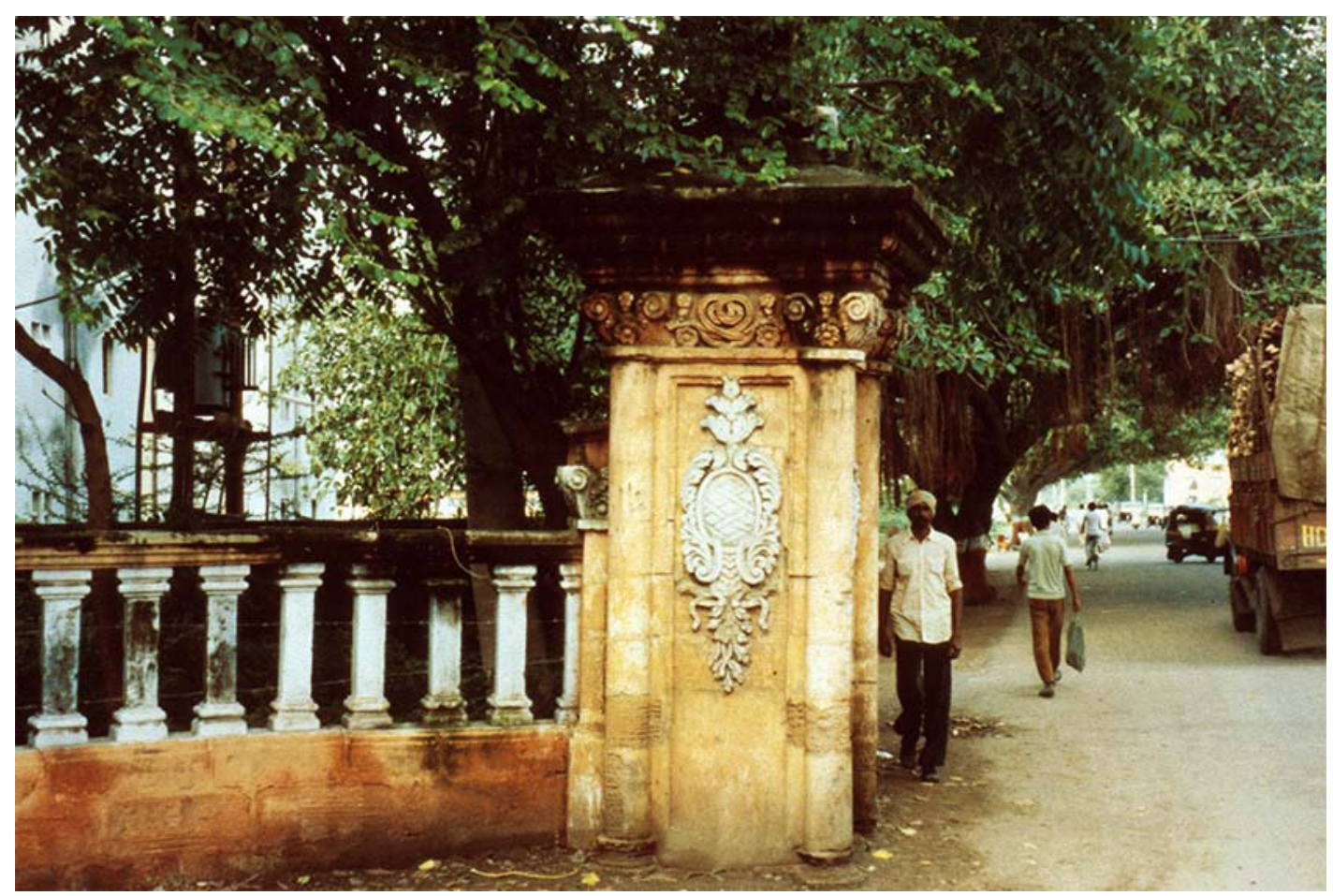

Figure 3

5 Jamnagar was one of the many semi-autonomous princely states that were allowed to govern themselves within British India, hence retaining a functioning royal household right through to Indian independence in 1947. 
Figure 4 is a photograph I took on the same spot some five years later. The balustrade had not been deliberately destroyed as far as I know, it had simply crumbled through neglect and perhaps the odd traffic collision.

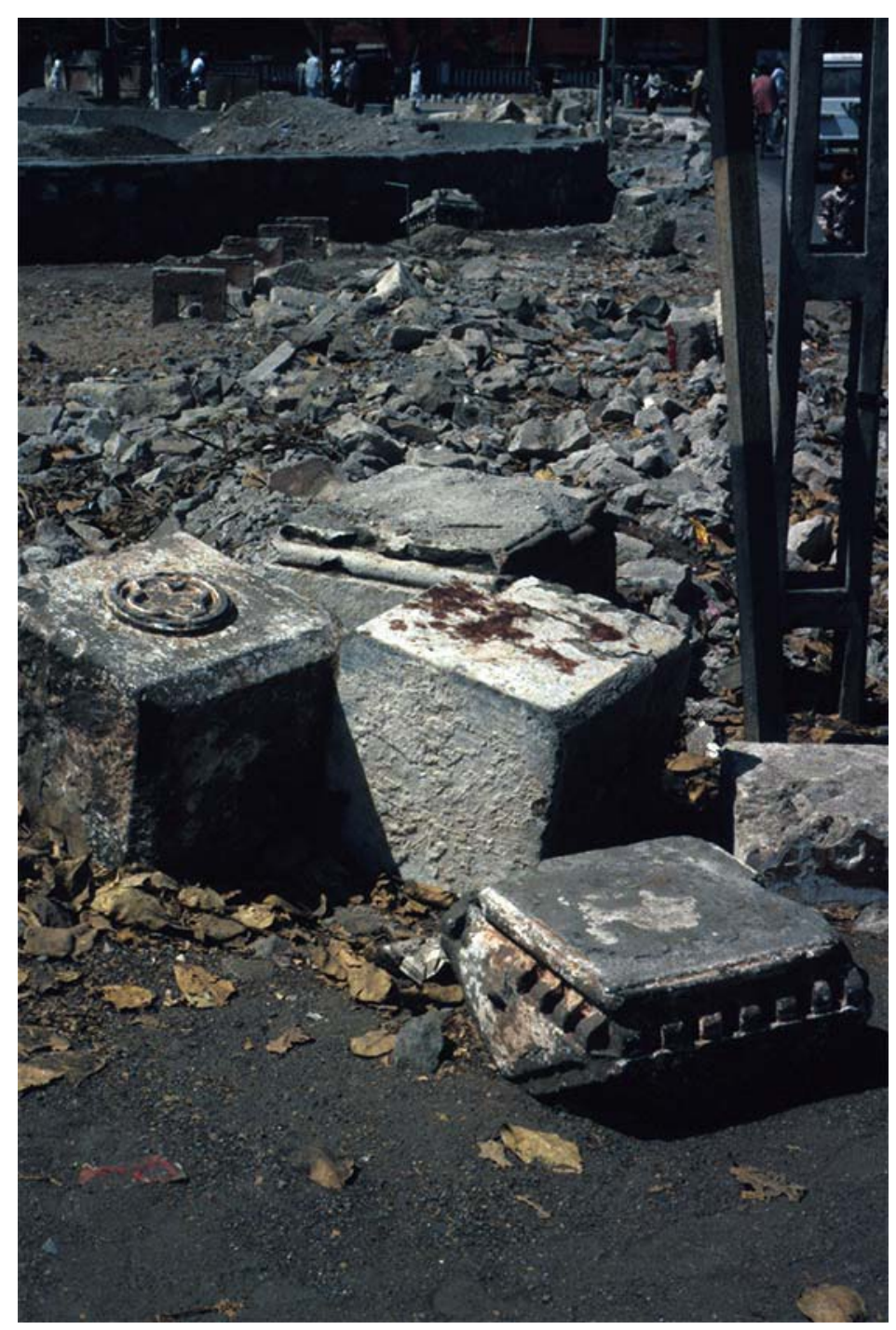

Figure 4

Finally, Figure 5 is a photograph I took at exactly the same spot - or as close as I could approximate it - some ten years later again, in 1999. The balustrade, and indeed the entire roadway, had vanished in an episode of planned development the year before, to be replaced with a new traffic intersection and a smart new roundabout (to the best of my knowledge, there were no roundabouts in the entire city when I first began work there in 1983).

My initial response to these changes, a response which motivated my photographs of them, was one of mild sadness, even nostalgia. At the time of my first stay in the city, in the early 1980s, I had found the "Parisian" aspects of the city faintly ridiculous, an exemplification of the empty pretentions of a puppet ruler, ${ }^{6}$ subsequently ignored and covered over by the inhabitants

6 Jam Ranjitsinji's extravagent expenditure, coupled with his inability to pay his bills, was evident to the British Imperial administration from early on, when he was a student at Cambridge University; see Dumasia 1927 for a contemporary but fawning account of his rule and the architectural changes he brought about, and see Wilde 
in the post-independence years. But by $1999 \mathrm{I}$ had begun to miss them.

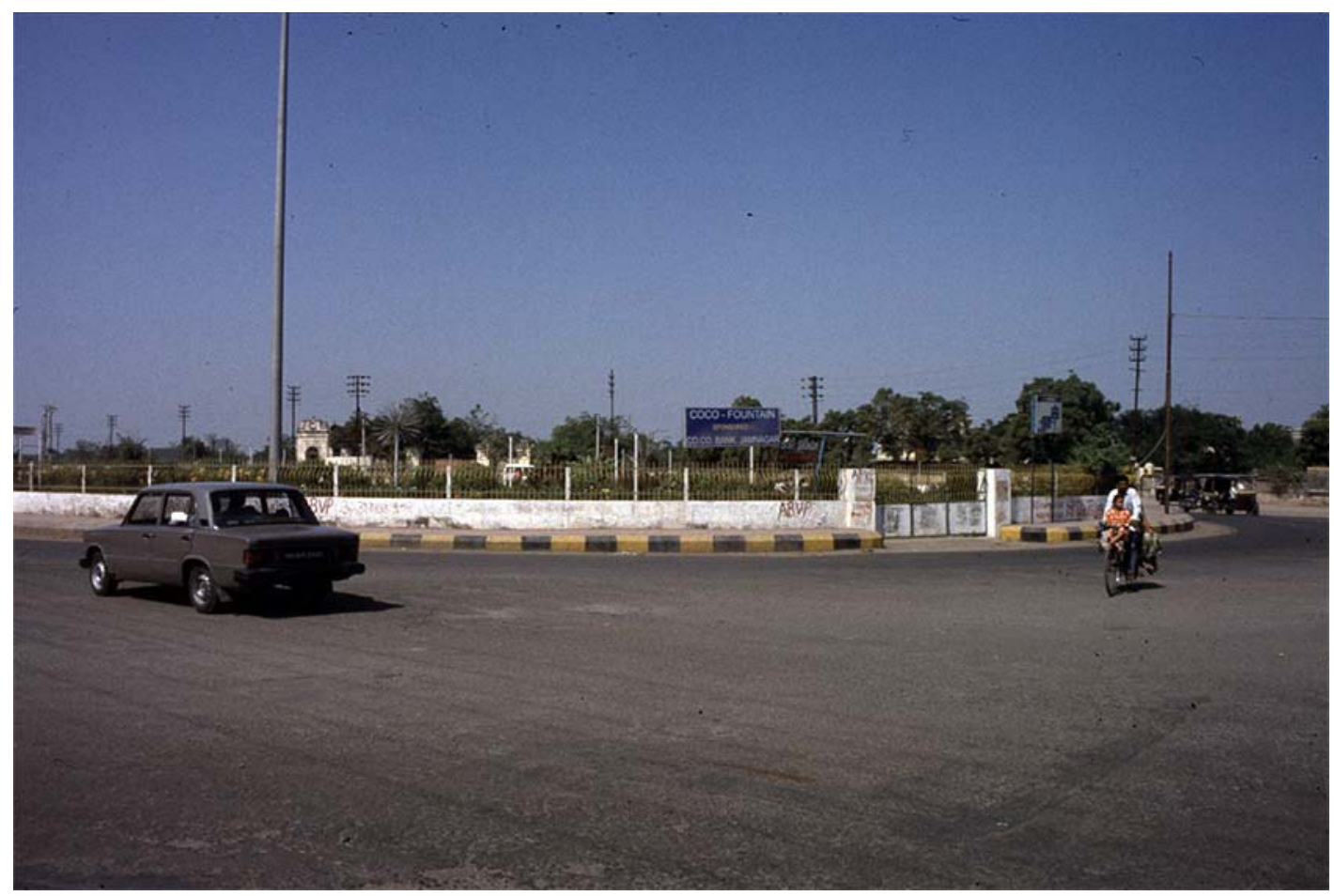

Figure 5

This sense of loss was compounded as I began to interview long term friends and acquaintances in 1999, when I returned after almost ten years' absence. Take for example, my close contact Naginbhai: a cloth merchant then in his late sixties, Naginbhai held a lease on a shop on one of Ranjitsinji's wide boulevards in the centre of Jamnagar and directly adjacent to Ranjitsinji's main palace. This topography is not accidental. The central market area of Jamnagar is dominated by a group of imposing Jain temples, but also the royal household's (Hindu) temple and the main city mosque. For much of the past four hundred years, this area had been the multiple centre of the city: commercial, royal and religious.

The importance of Jamnagar's Jains in the commercial life of the city, and their close association with the Palace until Independence, is marked by their religious and commercial presence right in this heart. Shopkeepers like Naginbhai's grandfather and great-grandfather were the city's prominent citizens and when I last saw him in 1999 Naginbhai continued to be - and be regarded as - a good citizen, visiting the nearby temples daily, and playing a prominent role in the affairs of his community. But this way of life was passing. When I talked to him he sighed and told me that business at the shop was poor, that the centre of Jamnagar was dying. The Palace had been unoccupied since Independence in 1949 - the result of an ongoing dispute between the descendent of the last king and the Indian tax authorities it is rumoured - and its slide into decay seemed emblematic of the apparent decline in commercial activity in the area. For the rest of my visit I continued to interview and to photograph, but it was only on my return to the UK, when I began to think about the changes I had heard, seen, and photographed, and more particularly as I began to revisit my earlier photographs - to explore my own visual

1990 for a rather more critical account of his life and work, written half a century later. 
archive - that I began to gain a sense of what was happening.

In 1996 Reliance Industries began construction of what my informants told me was to be Asia's largest petrochemical plant, on an arid and sparsely populated coastline some $50 \mathrm{~km}$ to the west of Jamnagar. ${ }^{7}$ With a small airport, and a speedily upgraded rail link, Jamnagar became the resource base for the plant's construction and subsequent initial servicing. Jamnagar's local businessmen were quick to rise to the challenge.

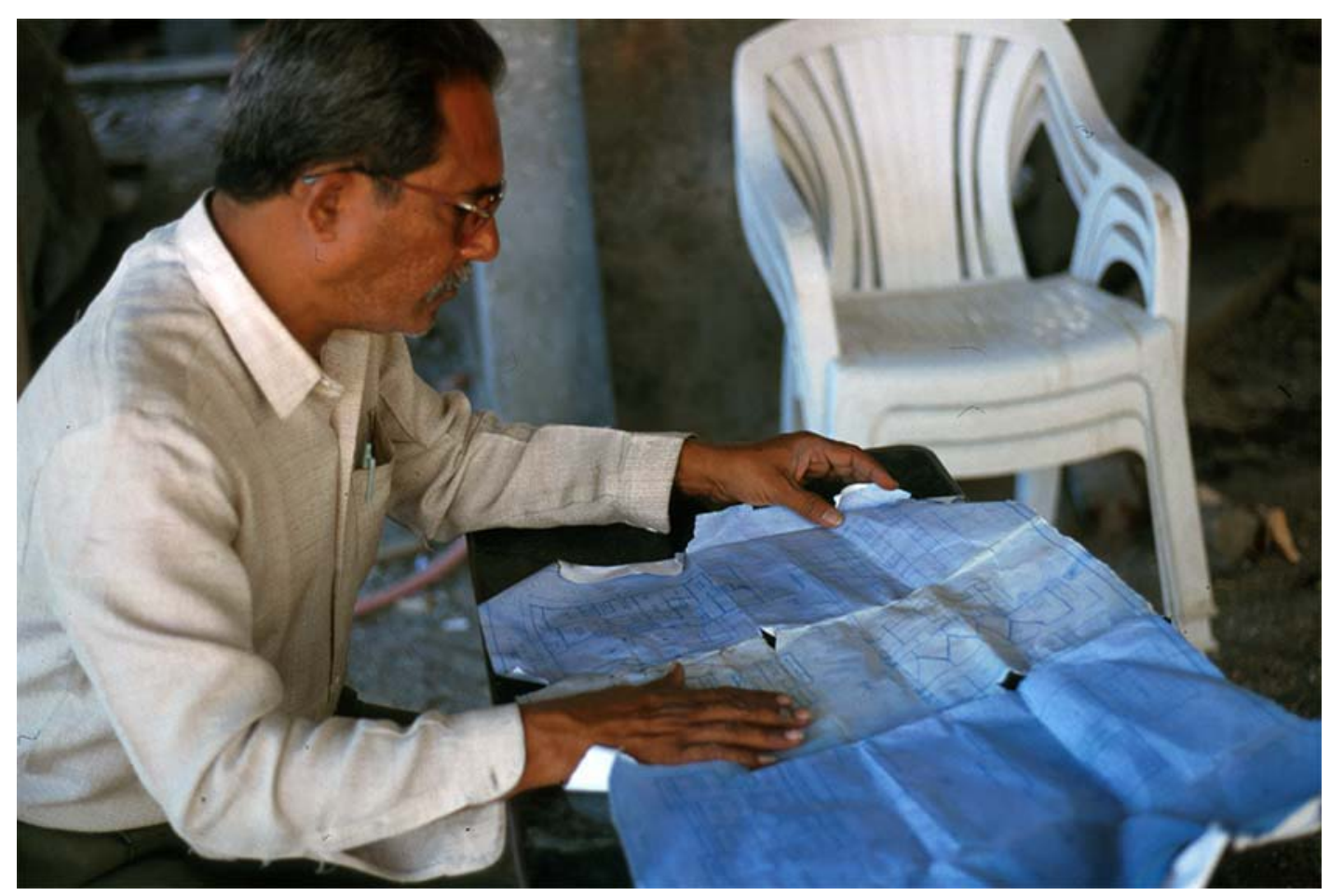

Figure 6

Figure 6 is a photograph, taken in 1999, of a close friend and informant studying blueprints for a small apartment complex he was constructing, as though he were a seasoned contractor. In reality for most of the preceding fifteen years I had known him he ran a small and - as far as I could I could tell - minimally profitable luggage shop in the main market area. The financing for the construction came from sources elsewhere within his extended family and loans. Similarly, my friend Naginbhai had told me that although he saw little future for his retail cloth shop in the main market area, he had gained the wholesale contract to supply all the bed linen for the petrochemical plant's workers' dormitories and that with his son he was planning to open a new retail outlet on the newly redeveloped main road that led to the airport.

As I continued to analyse my data (for a paper on changing Jain lifestyles - Banks 2003) I realized that my photographs from the early and mid-1980s could be read in dialogue with the photographs from the late 1990s in a conversation about changing power relationships. My earliest photographs of the "Parisian" features of the town had been taken with the intention of looking back, to Jamnagar's heyday in the 1920s when Ranjitsinji's reign was at its height. In conversation with the 1990s photographs however they now spoke about changing and evolv-

7 See <http://www.ril.com/html/aboutus/manufact_jamnagar.html $>$ for an overview. 
ing relationships in the present and into the future - not about relationships between individual people or groups of people, as White (2009) noted for the Connolly and Anderson "Highlands Trilogy" films, but relationships of power and governance. Despite his development of a "modern" city, and the advantages the developments had given to the mercantile class, represented by the majority of my research subjects in the 1980s, Ranjitsinji's urban planning had not generally been for the good of the population at large and had indeed disadvantaged Jamnagar as it joined independent India in $1947 .{ }^{8}$ It was really only the economic liberalization regime of the Indian government in the 1990s, signified locally by the arrival of the Reliance petrochemical plant, that new forms of power and new ways of understanding the relationship between money and persons could be formulated. What I had taken to be a successful but now fossilized mercantile class, had shown itself capable of seizing these opportunities.

This was represented all around me visually, but it was only when seen in the context of my earlier images that I could read the story of change as being more than a simple account of modernity and globalization. I do not claim that such insights are uniquely the product of visual research, but I do consider that allowing images the time and space in which to breathe, a space that includes their proximity to other images taken over time, is a particularly fruitful path to such insights.

\section{Conclusions}

Is "slow research", at least as I have described it here, always possible? Clearly some depth of time is a requirement and thus a resource available only to the researcher several or many years into her career, though time can be telescoped and earlier periods visually accessed with recourse to the visual archive of others. Yet as I mentioned at the start of this paper, funding constraints, and the agendas of funding bodies and career development do not always favour slow research either.

But just because it is not easy does not mean it should be ruled out completely. One of the great strengths - and frustrations - of film, photographs and other images is their refusal to be confined by either text or context. In each context, and accompanied by text in those cases where relevant, images speak with particular voices. But in other, later contexts, associated where relevant with other words, they speak in different ways. Allowing images the space and the time to breathe, by tailoring our research to their sometimes painfully slow agendas rather than the other way around, can yield great insight.

\section{References}

Banks, Marcus. 1992. Organizing Jainism in India and England. Oxford: Clarendon Press. 2003. "Indian Jainism as social practice at the end of the twentieth century", In Qvarnström, Olle Jainism and early Buddhism: essays in honour of Professor P.S. Jaini.

$8 \quad$ As Wilde notes "like the majority of the princes ... [Ranjitsinji] had never seen his primary responsibility as improving the welfare of his people" (1990: 235). 
Freemont, Ca.: Asian Humanities Press.

Banerjee, Mukulika and Daniel Miller. 2008. The sari. Oxford: Berg.

Bateson, Gregory and Margaret Mead. 1942. Balinese Character: A Photographic Analysis. New

York: New York Academy of Sciences.

Dumasia, Naoroji. 1927. Jamnagar: a sketch of its ruler and administration. Bombay: Times Press.

Edwards, Elizabeth. 2011. "Photographs: material form and the dynamic archive". In Caraffa,

Constanza (ed.) Photo archives and the photographic memory of art history. Berlin: Deutscher

Kunstverlag.

Foster, George, Thaya Scudder, Elizabeth Colson and Robert V. Kemper. 1979. "Introduction". In Foster, George, Thaya Scudder, Elizabeth Colson and Robert V. Kemper (eds) Longterm field research in social anthropology. New York: Academic Press.

Gardner, Robert and Karl Heider. 1969. Gardens of war: life and death in the New Guinea stone age. New York: Random House.

Goodman, Roger. 2000. "Fieldwork and reflexivity: thoughts from the anthropology of Japan". In James, Wendy, Paul Dresch and David Parkin (eds) Anthropologists in a wider world. Oxford: Berghahn.

Harper, Douglas. 1987. "The visual ethnographic narrative". Visual Antbropology 1.1:1-19.

Ingold, Tim and Jo Lee Vergunst. 2008. "Introduction". In Ingold, Tim and Jo Lee Vergunst (eds) Ways of walking: ethnography and practice on foot. Aldershot: Ashgate.

Lanning, Kevin, Samantha Montgomery, Justin Bright, Lenone Broming, Misty Hudelson, Rachel E. Pauletti, Garreth RosenZweig and Rachel Starkings. 2009. "Lives through film: $49 U_{p}$ and the $U_{p}$ series as a longitudinal study of personality and social change." In Gregerson, Mary Banks (ed.) The cinematic mirror for psychology and life coaching. New York: Springer.

MacDougall, David. 2006. The corporeal image: film, ethnography and the senses. Princeton NJ: Princeton University Press.

Mitchell, W. J. Thomas. 2005. What do pictures want? The lives and loves of images. Chicago: University of Chicago Press.

Morphy, Howard and Marcus Banks. 1997. "Introduction: rethinking visual anthropology". In Banks, Marcus and Howard Morphy (eds) Retbinking visual anthropology. London and New Haven: Yale University Press.

Parkin, David. 2000. "Templates, evocations and the long-term fieldworker". In James, Wendy, Paul Dresch and David Parkin (eds) Anthropologists in a wider world. Oxford: Berghahn.

Pink, Sarah. 2007. "Walking with video”. Visual Studies 22.3: 240-252. 2008. "Sense and sustainability: The case of the Slow City movement". Local Environment 13.2: 95-106. 2009. Doing sensory ethnography. London: Sage.

Ruspini, Elisabetta. 2000. "Longitudinal research in the social sciences”. Social Research Update, Issue 20, Spring 2000.

Scudder, Thaya and Elizabeth Colson. 2002. "Long term field research in Gwembe Valley, Zambia". In Kemper, Robert V. and Anya Petersen Royce (eds) Chronicling cultures: long-term field research in anthropology. Walnut Creek, CA: Altamira Press.

Singer, Bennett L., and Michael Apted. 1998. Forty-two up. New York: The New Press.

Solnit, Rebecca. 2003. Motion studies: time, space and Eadweard Muybridge. London: Bloomsbury

White, Miranda. 2009. Longitudinal studies in visual research: a potential methodology for the discipline. Unpublished coursework assignment, MSc Visual Anthropology. Oxford: University of Oxford.

Wilde, Simon. 1990. Ranji: a genius rich and strange. London: Kingswood Press. 
Vogt, Evon Z. (ed.). 1974. Aerial photography in anthropological field research. Cambridge, Mass.: Harvard University Press. 